\title{
TRlzol treatment of secretory phase endometrium allows combined proteomic and mRNA microarray analysis of the same sample in women with and without endometriosis
}

\author{
Amelie Fassbender, Peter Simsa, Cleophas M Kyama, Etienne Waelkens, Attila Mihalyi, Christel Meuleman, \\ Olivier Gevaert, Raf Van de Plas, Bart de Moor and Thomas M D'Hooghe 1,2,3,4*
}

Since publication of our article [1], we have realised that we did not include the full data in Table 1 and missed the word (TOF) in the result/discussion section. We have provided here the adapted sentence and another version of the table, including all the information intended.

\section{Results/Discussion}

"Therefore, we plan to repeat this study in a larger sample size including well defined endometrial samples obtained during menstrual, follicular and secretory phase, to validate the reproducibility of SELDI-TOF MS technology in these samples and to identify the protein

Table 1 The representative molecular weights of the proteins identified in the mRNA Microarray study [Thirteen] [2]

Protein
Osteoglycin (OGN/4969)
Interleukin-6 signal transducer (IL6ST/3572)
Cytochrome P450, Family 2, Subfamily J, polypeptide 2 (CYP2J2/1573)
Carboxypeptidase E (CPE/1363)

Mass in $\mathrm{Da}$

Fibronectin 1 (FN1/2335)

Mass in Da
33,922
isoform 1103,537
isoform 237,499
57,611
53,151
different isoform
1. 262,607
2. 71,943
3. 259,198
4. 222,944
5. 243,316
6. 240,477
7. 268,894
8. 252,793
9. 246,670
10. 239,608
11. 262,388
12. 221,274
13. 249,304
14. 249,384

* Correspondence: thomas.dhooghe@uzleuven.be

'Leuven University Fertility Centre, Department of Obstetrics \& Gynaecology,

University Hospital Gasthuisberg, Leuven, Belgium

Full list of author information is available at the end of the article 
Table 1 The representative molecular weights of the proteins identified in the mRNA Microarray study [Thirteen] [2] (Continued)

\begin{tabular}{ll}
\hline & $15.272,302$ \\
Synuclein, gamma (SNCG/6623) & 13,331 \\
BAI1-associated protein 2 (BAIAP2/10458) & different isoforms \\
& $1.60,868$ \\
& $2.59,014$ \\
& $3.56,626$ \\
Protocadherin 17 (PCDH17/27253) & $4.57,359$ \\
& $5.57,445$ \\
Protein tyrosine phosphatase, receptor type, R (PTPRR/5801) & $6.57,430$ \\
& different isoforms \\
& $1.126,229$ \\
& $2.96,570$ \\
& Alpha $73,834 \mathrm{Da}$ \\
& Gamma $46,581 \mathrm{Da}$ \\
\hline
\end{tabular}

peaks observed after proteomic analysis, which are expensive and labour intense requiring High-performance liquid chromatography or high-pressure liquid chromatography (HPLC) and matrix assisted laser desorption ionization Time-of-Flight-Mass Spectrometry (MALDI-TOF/ TOF MS)."

\section{Author details}

'Leuven University Fertility Centre, Department of Obstetrics \& Gynaecology, University Hospital Gasthuisberg, Leuven, Belgium. ${ }^{2}$ Division of Reproductive Health and Biology, Institute of Primate Research, P.O. Box 24481-00502 Karen, Nairobi, Kenya. ${ }^{3}$ Biochemistry Section, Department of Molecular Cell Biology, Campus Gasthuisberg, Leuven, Belgium. ${ }^{4}$ Department of Electrical Engineering, ESAT-SCD, K.U.Leuven, Kasteelpark-Arenberg 10, B-3001

Heverlee, Belgium

Received: 29 March 2011 Accepted: 6 April 2011 Published: 6 April 2011

\section{References}

1. Fassbender Amelie, Simsa Peter, Kyama MCleophas, Waelkens Etienne, Mihalyi Attila, Meuleman Christel, Gevaert Olivier, Van de Plas Raf, de Moor Bart, D'Hooghe MThomas: TRIzol treatment of secretory phase endometrium allows combined proteomic and mRNA microarray analysis of the same sample in women with and without endometriosis. Reproductive Biology and Endocrinology 2010, 8:123.

2. Sherwin JR, Sharkey AM, Mihalyi A, Simsa P, Catalano RD, D'Hooghe TM: Global gene analysis of late secretory phase, eutopic endometrium does not provide the basis for a minimally invasive test of endometriosis. Hum Reprod 2008, 23(5):1063-1068.

doi:10.1186/1477-7827-9-44

Cite this article as: Fassbender et al.: TRlzol treatment of secretory phase endometrium allows combined proteomic and mRNA microarray analysis of the same sample in women with and without

endometriosis. Reproductive Biology and Endocrinology 2011 9:44.

\section{Submit your next manuscript to BioMed Central} and take full advantage of:

- Convenient online submission

- Thorough peer review

- No space constraints or color figure charges

- Immediate publication on acceptance

- Inclusion in PubMed, CAS, Scopus and Google Scholar

- Research which is freely available for redistribution

Submit your manuscript at www.biomedcentral.com/submit
C Biomed Central 